\title{
YEAST PROTEINASE IN BEER
}

\author{
by \\ THOMAS DREYER, KIRSTEN BIEDERMANNx) \\ and \\ MARTIN OTTESEN \\ Department of Chemistry, Carlsberg Laboratory \\ Gamle Carlsberg Vej 10, DK-2500 Copenhagen Valby \\ x) Present address: Friedrich Miescher Institut, \\ Postfach 273, CH-4002, Basel, Switzerland
}

Keywords: Acid proteinase, aspartate proteinase, brewers' yeast proteinase, beer foam

\begin{abstract}
A sensitive assay for acid proteinases, based on tritium labelled hemoglobin, has been used to demonstrate nanogram quantities of acid proteinase in unpasteurized commercial beers. The proteinase was released from brewers' yeast into beer, and the level varied both with the yeast strain used and with other process parameters. Acid proteinase was isolated from brewers' yeast and added to beer in amounts similar to the highest activities found in beer samples. This caused a significant reduction in beer foam stability.
\end{abstract}

\section{INTRODUCTION}

Proteolytic enzymes from malt have an important role in beer production since they degrade proteins during the mashing step. When the wort is boiled these enzymes are destroyed, and it is normally assumed that no further proteolysis occurs in the subsequent fermentation and maturation steps (5). However, this assumption may not be totally correct since proteolytic enzymes could escape from damaged yeast cells. Several proteolytic enzymes have been found in brewers' yeast and one of these has an acid $\mathrm{pH}$ optimum suggesting that it would be active in fermenting beers $(10,17,18)$. In the present report a sensitive proteinase assay has been applied to commercial beers and widely different levels of acid proteinase activity were found. The acid proteinase was isolated from brewers' yeast and added to samples of beer. In amounts which corresponded to the highest levels observed in commercial beer, this proteinase significantly decreased the half-life of beer foams. 


\section{MATERIALS AND METHODS}

\subsection{Materials}

Brewers' yeast was obtained from The United Breweries Ltd. (Copenhagen, Denmark). Bovine hemoglobin and ethylene glycol were from Merck (Darmstadt, W. Germany) and $\left({ }^{3} \mathrm{H}\right)$-sodium borohydride, $8.4 \mathrm{Ci} \cdot \mathrm{mol}^{-1}$, from New England Nuclear (Boston, USA). Pepsin, 2710 $\mathrm{U} \cdot \mathrm{mg}^{-1}$, lot No. 45C-8231 from hog pancreas, was from Sigma (St. Louis, USA).

DEAE-Sephacel and Phenyl Sepharose CL-4B were from Pharmacia (Uppsala, Sweden). An affinity resin for carboxypeptidase $\mathrm{Y},((\mathrm{N}-\varepsilon-$ aminocaproyl)-p-aminobenzyl)succinyl-Sepharose (CABS-Sepharose) was kindly donated by K. Breddam $(2,6)$. All other chemicals were analytical grade.

\subsection{Methods}

\subsubsection{Activity measurements}

Hemoglobin was radioactively labelled by reductive methylation $(11,13,14)$ with formaldehyde plus ( $\left.{ }^{3} \mathrm{H}\right)$-sodium borohydride according to $\mathrm{TACK}_{\mathrm{A}}$ et al. (16). The labelled hemoglobin was denatured by exhaustive dialysis against 0.1 $\mathrm{M}-\mathrm{KCl}$ adjusted with $\mathrm{HCl}$ to $\mathrm{pH} 2.5$. From liquid scintillation counting and the protein content, determined by amino acid analysis, a specific activity of $31 \mathrm{Ci} \cdot \mathrm{mmol}^{-1}$ was found. Approximately $40 \%$ of the lysine $\varepsilon$-amino groups were dimethylated.

Acid proteinase activity was determined by the LANOË and DUNNIGAN modification of the Anson method $(1,8)$. Aliquots of $125 \mu \mathrm{l} 2 \%$ hemoglobin, $\mathrm{pH} 2.5$, containing $5 \times 10^{5} \mathrm{cpm}\left({ }^{3} \mathrm{H}\right)$ hemoglobin, were mixed with $125 \mu \mathrm{l}$ beer samples, and trichloroacetic acid soluble peptides were determined by liquid scintillation counting. Blank values were determined using boiled beer samples. Acid proteinase activity was arbitrarily expressed as the number of pepsin units which digested hemoglobin to the same extent. All beer samples were clarified by centrifugation, in order to remove yeast and hop particles. Incubation with substrate lasted 48 hours, and microbial growth was prevented by addition of $100 \mathrm{ppm}$ penicillin $G$ and 1 ppm streptomycin sulphate.

\subsubsection{Isolation of acid proteinase}

$5 \mathrm{~kg}$ brewers' yeast, which had been sieved free of hop particles and washed with ice-cold distilled water, was plasmolysed for one hour with $500 \mathrm{ml}$ of ether. Then $5 \mathrm{I}$ water was added, $\mathrm{pH}$ adjusted to 7.5 and the autolysate left standing at $25{ }^{\circ} \mathrm{C}$ for 21 hours. After centrifugation at $7,500 \times \mathrm{g}$ for $30 \mathrm{~min}, \mathrm{pH}$ was adjusted to 5.0 with $20 \%$ acetic acid, and the supernatant was activated by standing for 20 hours at $25^{\circ} \mathrm{C}$. After another centrifugation $0.5 \mathrm{~mm}$-mercuric chloride was added to suppress proteinase $B$ activity (7). This had no inhibitory effect on the acid proteinase. The proteinases were precipitated at $94 \%$ saturation with ammonium sulphate. After centrifugation distilled water was added to the precipitate until it was $20 \%$ saturated with ammonium sulphate. The solution was clarified by centrifugation and applied to a $500 \mathrm{ml}$ PhenylSepharose 4B column $(10 \times 6.5 \mathrm{~cm})$, washed at $500 \mathrm{ml} \cdot \mathrm{h}^{-1}$ with $1000 \mathrm{ml} 10 \%$ saturated ammonium sulphate in $0.1 \mathrm{~m}$-potassium phosphate, $\mathrm{pH} 6.0$, and at $100 \mathrm{ml} \cdot \mathrm{h}^{-1}$ with $500 \mathrm{ml}$ of the same buffer containing $50 \%$ ethylene glycol (v) v). The proteinase was eluted at $100 \mathrm{ml} \cdot \mathrm{h}^{-1}$ with $1000 \mathrm{ml}$ buffer containing $85 \%$ ethylene glycol (v/v), as described by MEUSSDOERFFER et al. (12). The eluate was concentrated to $250 \mathrm{ml}$ by diafiltration against $0.1 \mathrm{M}$-potassium phosphate, $\mathrm{pH} 7.0$, and applied to a $500 \mathrm{ml}$ DEAE-Sephacel column $(5 \times 8 \mathrm{~cm})$, equilibrated with the same buffer. After washing with $600 \mathrm{ml}$ buffer, the enzyme was eluted at $100 \mathrm{ml} \cdot \mathrm{h}^{-1}$ with a 1.61 linear gradient from $0-0.5 \mathrm{M}-\mathrm{NaCl}$ in $0.1 \mathrm{M}$-potassium phosphate, $\mathrm{pH} 7.0,0.5 \mathrm{~mm}$-mercuric chloride. Fractions containing acid proteinase activity were pooled, diafiltered against $0.05 \mathrm{M}$-ammonium acetate, $\mathrm{pH} 5.0$, and concentrated to 50 ml. $1 \mathrm{~mm}$-cysteine was added in order to prevent $\mathrm{Hg}++$ from forming complexes with carboxypeptidase $Y$, and the solution was quickly passed through a $4 \mathrm{ml}$ CABS-Sepharose affinity column, to remove this contaminating enzyme. The eluate was concentrated by ultrafiltration to $25 \mathrm{ml}$, and stored in $1 \mathrm{ml}$ aliquots at $-23{ }^{\circ} \mathrm{C}$. The acid proteinase had a specific activity against acid denatured hemoglobin which was approximately $10 \%$ of the specific activity of pepsin. 
Table I.

Acid proteinase activity in beer measured during fermentation and maturation. Proteinase activity was measured in clarified beer samples using tritium labelled hemoglobin, as described in section 2.2.1. The activity is expressed in pepsin equivalents units per liter.

\begin{tabular}{ccccc}
\hline Beer & \multicolumn{2}{c}{ Fermentation } & \multicolumn{2}{c}{ Maturation } \\
\cline { 2 - 5 } & $\begin{array}{c}\text { No. of } \\
\text { samples }\end{array}$ & U/1 & $\begin{array}{c}\text { No. of } \\
\text { samples }\end{array}$ & U/1 \\
\hline A & 3 & $<10$ & 2 & $<10$ \\
B & 6 & $<10$ & 6 & $<10-80$ \\
C & 2 & $60-90$ & 3 & $130-150$ \\
D & 5 & $180-300$ & 5 & $150-300$ \\
\hline
\end{tabular}

\section{RESULTS AND DISCUSSION}

\subsection{Acid proteinase activity in beers}

The use of tritium labelled acid denatured hemoglobin to measure acid proteinase activity in beer, as described in section 2.2.1, allows a limit of detection of $10 \mathrm{U}$ pepsin activity per liter. This high sensitivity can be obtained because the method is independent of the numerous UV-absorbing compounds in beer. Using either pepsin or purified acid proteinase from brewers' yeast, linear standard curves were obtained up to approximately 300 units per liter, and acid proteinase added to beer was recovered in $100 \pm 10 \%$ yield.

Four different commercial beers were selected for measurements of acid proteinase activity in unpasteurized samples. The results presented in Table I indicated very low acid proteinase activity in Beer A, below $10 \mathrm{U} / 1$. In Beer B the level was similarly below $10 \mathrm{U} / \mathrm{l}$ after the main fermentation, but during maturation the proteinase level increased, and the highest value observed was $80 \mathrm{U} / \mathrm{l}$. The same tendency was observed in Beer $\mathrm{C}$, but the levels were higher with a proteinase content which averaged $80 \mathrm{U} / \mathrm{l}$ after fermentation, and $140 \mathrm{U} / \mathrm{l}$ after maturation. In Beer $D$ the acid proteinase activity was equally high after fermentation and after maturation, with an average of approximately $200 \mathrm{U} / \mathrm{l}$. Since Beers A and B were pitched with the same yeast strain, while another yeast strain had been used for Beers $C$ and $D$, these results suggest that the nature of the yeast strain influence the proteinase levels in the beer. This might reflect dif- ferent cell wall permeability characteristics in the yeast strains, since MADDOX and HouGH (9) previously have demonstrated leaking of intracellular proteinases through the cell wall of living brewers' yeast grown in a synthetic medium containing protein, glucose and mannose. The present results indicate, that a leaking of proteolytic enzymes also occur during normal beer fermentation procedures. However, since significant differences also were observed between proteinase levels of beers brewed with the same yeast strain, it is likely that other beer processing variables than the strain of yeast influence the leaking of proteinase.

\subsection{Addition of yeast acid proteinase to beer}

Acid proteinase, isolated from brewers' yeast as described in section 2.2.2, was homogenous in polyacrylamide gel electrophoresis in Trisglycine buffer, $\mathrm{pH} 8.3$ (4). It was inhibited by pepstatin like proteinase A from Saccharomyces cerevisiae (15). The enzyme had a molecular weight of approximately 40,000 dalton, as determined by SDS-polyacrylamide gel slab electrophoresis. The same value was found after reduction with $5 \%$ dithiothreitol, indicating that the enzyme consists of a single peptide chain. Analytical isoelectric focusing showed three bands within a narrow range from pI 3.5-4.0. The purified acid proteinase was added to a sample of Beer $C$, in which the original proteinase activity had been destroyed by pasteurization. The acid proteinase was added in amounts varying from 0 to $500 \mathrm{U} / \mathrm{l}(0-1,600 \mu \mathrm{g} / \mathrm{l})$ and as seen in Figure 1, the foam half-lives were reduced with increasing levels of enzyme activity. The effect of addition of pepsin was examined at similar activity levels, and it is seen that the acid yeast proteinase was equally efficient as pepsin in destroying foam active proteins. These results indicate, that the acid proteinase, at the activity levels found in Beer D, may have a detrimental effect on foam stability. This is consistent with foam stability problems observed in Beer D, and it suggests that proteolytic enzymes from the brewers' yeast may digest wort proteins responsible for beer foam stability, leaving peptides with reduced or no foaming properties.

Further experiments are however required to elucidate the mechanism behind the release of 


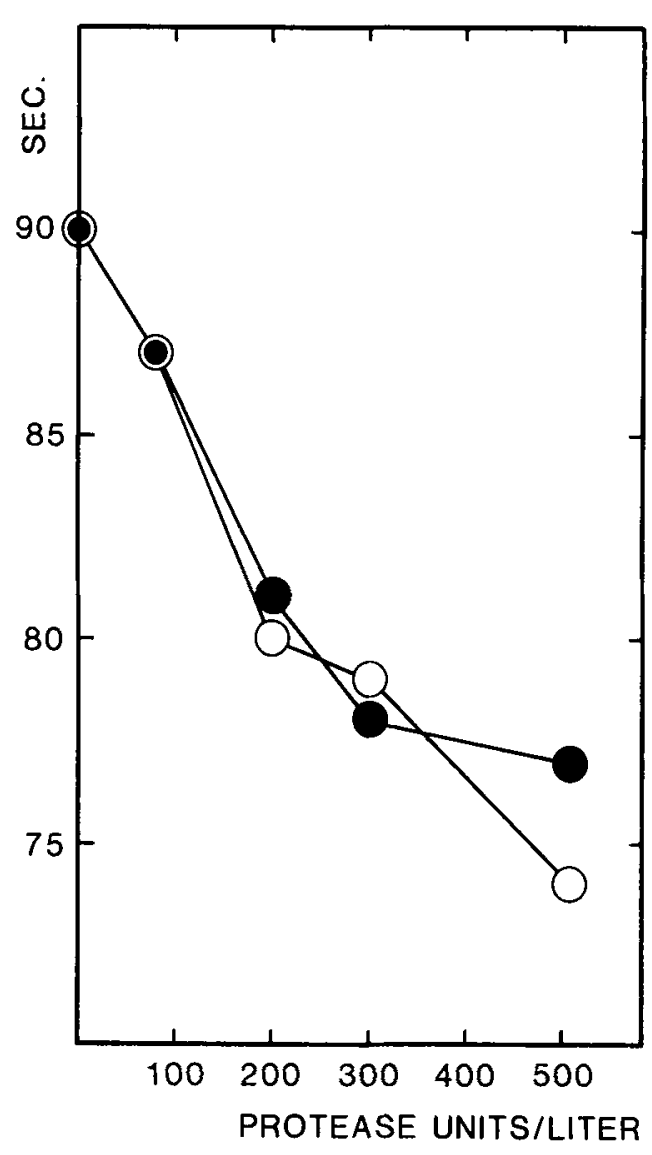

Figure 1. Foam half-lives of beers after incubation with acid proteinase from brewers' yeast (filled circles) and pepsin (open circles).

After addition of $800 \mu \mathrm{l}$ enzyme solution to each $330 \mathrm{ml}$ bottle of Beer C, bottle headspaces were flushed with $\mathrm{CO}_{2}$, and the bottles were crowned. After 72 hours of incubation at $10^{\circ} \mathrm{C}$, beer foam half-lives were measured according to Вцом (3).

proteinases, as well as the effect of variations in the physical and chemical environment of the yeast on the proteinase efflux.

\section{ACKNOWLEDGEMENTS}

The authors wish to thank Research Manager B. Ahrenst-Larsen and cand. polyt. T. Mathiasen for stimulating discussions. The excellent technical assistance of Sidsel EhLERS is greatly acknowledged, and we thank J.C. LORENZEN at the Central Laboratory, The United Breweries Ltd. for the analysis of beer foam stability.

\section{REFERENCES}

1. ANSON, M.L.: The estimation of pepsin, trypsin, papain and cathepsin with hemoglobin. J. Gen. Physiol. 22, 79-89 (1939)

2. Bazzone, T.J., M. Sokolovsky \& L.B. AiEnI: Single-step isolation and resolution of pancreatic carboxypeptidase A and B. Biochemistry 18, 4362-4366 (1979)

3. Blom, J.: Über die Bestimmung der Haltbarkeit des Schaumes. Europ. Brewery Conv. Congr. Proc. Copenhagen 1957, 51-56 (1957)

4. Davis, B.J.: Disc electrophoresis II. Method and application to human serum proteins. Ann. N.Y. Acad. Sci. 121, 404-427 (1964)

5. Hough, J.S., D.E. Briggs, R. Stevens \& T.W. YouNG: Malting and brewing science, vol. 2, Sec. ed., Chapman and Hall, London and New York (1982)

6. Johansen, J.T., K. Breddam \& M. Ottesen: Isolation of Carboxypeptidase $\mathrm{Y}$ by affinity chromatography. Carlsberg Res. Commun. 41, 1-14 (1976)

7. Kominami, E., H. Hoffschulte \& H. Holzer: Purification and properties of proteinase $B$ from yeast. Biochem. Biophys. Acta 661, 124$135(1981)$

8. Lanoë, J. \& J. Dunnigan: Improvements of the Anson assay for measuring proteolytic activities in acidic pH range. Anal. Biochem. 89, 461-471 (1978)

9. Maddox, I.S. \& J.S. Hough: Proteolytic enzymes and autolysing Brewers' yeast. Europ. Brewery Conv. Congr. Proc. Interlaken, 1955 315-325 (1955)

10. Maddox, I.S. \& J.S. Hough: Proteolytic enzymes of Saccharomyces carlsbergensis. Biochem. J. 117, 843-852 (1970)

11. Means, G.E. \& R.E. FeEney: Reductive alkylation of amino groups in proteins. Biochemistry 7, 2192-2201 (1968)

12. Meussdoerffer, F., P. Tortora \& H. Holzer: Purification and properties of proteinase $A$ from yeast. J. Biol. Chem. 255, 12087-12093 (1980)

13. Ottesen, M. \& B. Svensson: Use of reductive methylation for radioactive labelling of proteins. Compt. Rend. Trav. Lab. Carlsberg 38, 445-456 (1971)

14. Rice, R.H. \& G.E. Means: Radioactive labelling of proteins in vitro. J. Biol. Chem. 246, 831$832(1971)$

15. SaheKr, T., Y. Matsuda \& H. Holzer: Purification and characterization of macromolecular inhibitors of proteinase A from yeast. Eur. J. Biochem. 47, 325-332 (1974) 
16. Tack, B.F., J. Dean, D. Eilat, P.E. Lorenz \& A.N. SCHECHTER: Tritium labelling of proteins to high specific radioactivity by reductive methylation. J. Biol. Chem. 255, 8842-8847 (1980)

17. Wolf, D.H.: Control of metabolism in yeast and other lower eukaryotes through action of proteinases. Advances in Microbial Physiology 21, 267-338 (1980)

18. Woods, F.C. \& J.E. KINSELla: Isolation and properties of protease from Saccharomyces carlsbergensis. J. Food Biochem. 4, 79-98 (1980) 